\title{
ISOLATION OF BACTERIOCIN-PRODUCING LACTIC ACID BACTERIA FROM MEAT AND MEAT PRODUCTS AND ITS SPECTRUM OF INHIBITORY ACTIVITY
}

\author{
Renata Bromberg*; Izildinha Moreno; Cíntia Lopes Zaganini; Roberta Regina Delboni; Josiane de Oliveira \\ Instituto de Tecnologia de Alimentos, Campinas, SP, Brasil.
}

Submitted: November 04, 2003; Returned to authors: February 12, 2004; Approved: May 20, 2004.

\begin{abstract}
A total of 285 samples of meat and meat products were evaluated for the presence of bacteriocin-producing lactic acid bacteria by the "sandwich" test. From 174 of these samples, 813 strains of lactic acid bacteria were isolated. They were able to inhibit the growth of Staphylococcus aureus CTC 33 and/or Listeria innocua Lin 11. When evaluated by the well-diffusion assay, 128 of these strains inhibited the growth of the indicator strains. The inhibitory spectra of activity of the isolates were evaluated against a range of Gram-positive and Gramnegative test organisms. S. aureus was the most sensitive indicator tested, whereas Enterococcus faecalis and Lactobacillus plantarum were the most resistant ones. All the compounds produced by the lactic acid bacteria were fully or partially inactivated by some of the proteolytic enzymes, which indicates their proteinaceous nature. The antimicrobial activity of the bacteriocins produced by the lactic acid bacteria isolated in this work could act as a potential barrier to inhibit the growth of spoilage bacteria and foodborne pathogens.
\end{abstract}

Key words: bacteriocins, lactic acid bacteria, meat, inhibitory activity

\section{INTRODUCTION}

Recently attempts have been made to apply biopreservation techniques to meat products (18). These have involved the introduction of a competitive microflora of lactic acid bacteria as protective cultures for meat products, including bacteriocinproducing lactic acid bacteria and purified anti-listerial bacteriocins (12). Considering that bacteriocin-producing bacteria are isolated from foods that normally contain lactic acid bacteria, such as meat and dairy products, they have been consumed for a long time. Bacteriocins produced by lactic acid bacteria are defined as extracellularly produced primary or modified products of bacterial ribosomal synthesis, which can have a relatively narrow spectrum of bactericidal activity (4). Bacteriocin-producing strains can be used as part of or adjuncts to starter cultures for fermented foods in order to improve safety and quality. In this context, bacteriocins produced by lactic acid bacteria associated with meat, such as Pediococcus, Leuconostoc, Carnobacterium and Lactobacillus spp., are likely to have a much greater potential as meat preservatives
$(3,31,33,38)$. The possibility of exploiting bacteriocins in food fermentation arises where the inhibitory spectrum includes food spoilage and/or pathogenic microorganisms, giving the producing strain a competitive advantage in the food. An important advantage of bacteriocins over classical antibiotics is that the digestive enzymes destroy them (4). This fact indicates that the ingestion of these compounds will not alter digestive tract ecology and also that will not cause risks related to the use of common antibiotics.

Bacteriocins could be applied in hurdle technology, which takes advantage of the synergies of combined treatments to preserve food more effectively (6). The use of nisin, a bacteriocin produced by Lactococcus lactis ssp., is currently allowed in about 50 countries. Nevertheless, some researchers concluded that nisin is not effective in meat application due to the high $\mathrm{pH}$ (24), difficulty to uniformly distribute the bacteriocin throughout the food and interference by meat components such as phospholipids (8) and glutathione (26). Due to the difficulties in using nisin in meat applications, the search for new bacteriocin-producing cultures should continue.

*Corresponding author. Mailing address: Instituto de Tecnologia de Alimentos, ITAL, Av. Brasil 2880. 13073-001, Campinas, SP, Brasil. Tel.: (+5519) 37431878. Fax: (+5519) 37431882. E-mail: renatab@ital.sp.gov.br 
The aim of this study was to screen a range of meat and meat products for the presence of bacteriocin-producing strains that might be valuable for use in biopreservation strategies for meat products. Thus, the potential of the isolates to inhibit food spoilage and foodborne pathogenic bacteria was evaluated.

\section{MATERIALS AND METHODS}

\section{Bacterial strains and growth media}

The strains used in this study are listed in Table 1. The bacteria chosen as indicators were Staphylococcus aureus CTC 33 (Instituto de Tecnologia de Alimentos - ITAL, Campinas, Brazil), Listeria innocua Lin 11 (Pasteur Institute, Paris, France), and Bacillus cereus CTC 1 (ITAL). The bacteriocin-producing Lactobacillus casei LC 705 (Wiesby) was used as the positive control. The stock cultures of lactic acid bacteria and the other microorganisms were maintained at $-80^{\circ} \mathrm{C}$ in de Man Rogosa Sharpe broth (MRS, Oxoid Ltd., Basingstoke, UK) or in Trypticase Soya broth (TSB, Oxoid) supplemented with 15\% glycerol. Working cultures were prepared as slants on MRS agar for lactic acid bacteria or TSA agar with $0.6 \%$ yeast extract (Oxoid) supplement for the indicators, and stored at $4^{\circ} \mathrm{C}$. Cultures for experiments were streak-plated once a week and inoculated into media from a single colony and incubated for $24 \mathrm{~h}$. Before use, the lactic acid bacteria cultures were transferred twice into the appropriated medium, and incubated according to the conditions showed in Table 1.

\section{Samples}

Two hundred and eighty five samples of a variety of meats and meat products obtained from different Brazilian manufacturers were analysed. They included fresh meat, raw, cooked, matured, dried or fermented meat products. After purchase in retail market, all the samples were stored at $3 \pm 1^{\circ} \mathrm{C}$ for up to a maximum of $24 \mathrm{~h}$ before analysis.

\section{Isolation of bacteriocin-producing lactic acid bacteria from meat}

A 25-g portion of each meat sample was aseptically transferred to a sterile stomacher bag and $225 \mathrm{~mL}$ of Buffered Peptone Water (BPW, Oxoid) added to obtain a 1:10 dilution. The samples were blended for 1 min using a stomacher (Model 400 - BA 7021, Seward Medical, London, UK). Serial dilutions of the samples were made in $0.1 \%$ peptone water. For detection of antagonistic activity, a "sandwich" test was used (37). For this purpose the dilutions were inoculated (pour plate) onto MRS agar supplemented with $0.01 \%$ sodium azide to inhibit Gram-negative bacteria. Inhibitory activity from the hydrogen peroxide was eliminated by the addition of catalase (Sigma Chemical Co., Dorset, UK) at a final concentration of 100 U. To rule out any inhibition due to $\mathrm{pH}$ reduction caused by organic
Table 1. Microorganisms and growth conditions.

\begin{tabular}{|c|c|}
\hline Microorganisms & Growth conditions \\
\hline \multicolumn{2}{|l|}{ Control } \\
\hline Lactobacillus casei LC 705 (Wiesbya) & $\mathrm{MRS}^{\mathrm{g}} 24 \mathrm{~h} / 30^{\circ} \mathrm{C}$ \\
\hline \multicolumn{2}{|l|}{ Indicators } \\
\hline Bacillus cereus ATCC 14579 & $\mathrm{TSB}^{\mathrm{h}} 24 \mathrm{~h} / 30^{\circ} \mathrm{C}$ \\
\hline B. cereus $\mathrm{CTC}^{\mathrm{c}} 1$ & $\mathrm{TSB} 24 \mathrm{~h} / 30^{\circ} \mathrm{C}$ \\
\hline Clostridium perfringens CTC 42 & $\mathrm{TSB} 24 \mathrm{~h} / 37^{\circ} \mathrm{C}$ \\
\hline Cl. sporogenes CTC 6 & $\mathrm{TSB} 24-48 \mathrm{~h} / 37^{\circ} \mathrm{C}$ \\
\hline Enterococcus faecalis ATCC 19433 & $\mathrm{TSB} 24 \mathrm{~h} / 30^{\circ} \mathrm{C}$ \\
\hline Escherichia coli ATCC 25422 & $\mathrm{TSB} 24 \mathrm{~h} / 37^{\circ} \mathrm{C}$ \\
\hline Lactobacillus helveticus (Wiesby) & MRS $24-48 \mathrm{~h} / 45^{\circ} \mathrm{C}$ \\
\hline Lb. plantarum TECNOLAT ${ }^{\mathrm{d}} 434$ & MRS $24 \mathrm{~h} / 30^{\circ} \mathrm{C}$ \\
\hline Leuconostoc mesenteroides ATCC 10830 & MRS $24 \mathrm{~h} / 30^{\circ} \mathrm{C}$ \\
\hline Listeria innocua $\operatorname{Lin} 11\left(\right.$ INRA $\left.^{\mathrm{e}}\right)$ & $\mathrm{TSB} 24 \mathrm{~h} / 37^{\circ} \mathrm{C}$ \\
\hline L. monocytogenes CTC 21 & $\mathrm{TSB} 24 \mathrm{~h} / 37^{\circ} \mathrm{C}$ \\
\hline Micrococcus sp. ATCC 4698 & $\mathrm{TSB} 24 \mathrm{~h} / 30^{\circ} \mathrm{C}$ \\
\hline Pseudomonas sp. CTC 32 & $\mathrm{TSB} 24 \mathrm{~h} / 37^{\circ} \mathrm{C}$ \\
\hline Salmonella typhimurium ATCC 14028 & $\mathrm{TSB} 24 \mathrm{~h} / 37^{\circ} \mathrm{C}$ \\
\hline Staphylococcus aureus CTC 33 & $\mathrm{TSB} 24 \mathrm{~h} / 37^{\circ} \mathrm{C}$ \\
\hline Streptococcus sp. ATCC 25175 & $\mathrm{TSB} 24 \mathrm{~h} / 30^{\circ} \mathrm{C}$ \\
\hline Sulphite-reducing clostridia CTC 5 & $\mathrm{TSB} 24 \mathrm{~h} / 37^{\circ} \mathrm{C}$ \\
\hline Weissella viridescens $\mathrm{CCT}^{\mathrm{f}} 849$ & $\operatorname{MRS} 24 \mathrm{~h} / 30^{\circ} \mathrm{C}$ \\
\hline
\end{tabular}

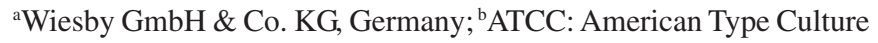
Collection, Rockville, MD, USA; ${ }^{\mathrm{c} C T C}$ : Centro de Tecnologia de Carnes, Instituto de Tecnologia de Alimentos, Campinas, S.P., Brazil; ${ }^{d}$ TECNOLAT: Centro de Tecnologia de Laticínios, Instituto de Tecnologia de Alimentos, Campinas, S.P., Brazil; 'INRA: Institute National de Recherches Agronomiques, Jouy-en-Josas, France; ${ }^{\mathrm{f} C C T}$ : Fundação Tropical André Tosello, Campinas, S.P., Brazil. ${ }^{\mathrm{g}} \mathrm{MRS}$ : de

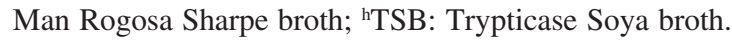

acid production, $2 \%$ sodium $\beta$-glycerophosphate (Ecibra, Brazil) was added to MRS agar. The plates were overlaid with the same media to exclude inhibition due to lytic bacteriophage, which are non-diffusing entities, followed by aerobic incubation at $35^{\circ} \mathrm{C}$ for $48 \mathrm{~h}$ to allow the colonies to develop.

After the incubation period, plates containing up to $10^{2} \mathrm{CFU}$ were overlaid with $4.5 \mathrm{~mL}$ of soft TSB (containing $0.75 \%$ agar). The overlay agar was seeded with $500 \mathrm{ml}$ of $S$. aureus CTC 33 or L. innocua Lin 11 at a level of $10^{6}$ to $10^{7} \mathrm{CFU} / \mathrm{mL}$. The plates were incubated at $35^{\circ} \mathrm{C}$ for $24 \mathrm{~h}$. Lysis of the indicator strains resulted in a clear zone. Colonies showing zones of inhibition were transferred to TSB and incubated at $30^{\circ} \mathrm{C}$ for up to $72 \mathrm{~h}$. The cultures were purified on MRS agar plates and incubated at $30^{\circ} \mathrm{C}$ for $18 \mathrm{~h}$. The purified isolates were examined by Gramstaining and catalase production, assayed according to Harrigan and McCance (10). 


\section{Detection of antagonistic activity}

Bacteriocin production by the lactic acid bacteria isolated from meat and meat products was assayed by the agar welldiffusion method according to Benkerroum et al. (1), this being a modification of that described by Tagg and McGiven (35). The plates were examined for lysis around the wells at different time intervals for a total of $24 \mathrm{~h}$. A direct comparison was made between the diameters of the zones of inhibition produced by different strains.

\section{Bacteriocin spectrum of inhibitory activity}

Bacteriocin-producing cultures isolated from meat and meat products were also tested against the strains of bacteria shown in Table 1. The well-diffusion assay was used as described before. The strains that presented a broad spectrum of activity were also assayed using the critical dilution assay of MayrHarting et al. (19). The title was defined as the reciprocal of the highest dilution showing an inhibition of the indicator strain multiplied by 100 to express the results as activity units per millilitre (AU/mL).

\section{Sensitivity of bacteriocin-like substance to enzymes}

Cell-free supernatants from the lactic acid cultures were collected by centrifugation $\left(7,500 \mathrm{~g}, 10 \mathrm{~min}, 4^{\circ} \mathrm{C}\right)$ of overnight MRS broth cultures. The supernatant fluids were adjusted to $\mathrm{pH} 6.5$ with $10 \mathrm{~N} \mathrm{NaOH}$ and exposed to heat $\left(95^{\circ} \mathrm{C}\right.$ for $\left.5 \mathrm{~min}\right)$ in a boiling waterbath. The supernatants were treated with the following enzymes at a final concentration of $0.2 \mathrm{mg} / \mathrm{mL}$ : ficin (Sigma Chemical Co., Dorset, England) in $20 \mathrm{mM}$ sodium phosphate, $\mathrm{pH} 7.0$; trypsin (Sigma) in $40 \mathrm{mM}$ Tris-HCl, pH 8.2; $\alpha$-chymotrypsin (Sigma) in $20 \mathrm{mM}$ Tris-HCl, $\mathrm{pH}$ 8.0; pronase $\mathrm{E}$ (Sigma) in $20 \mathrm{mM}$ Tris-HCl, pH 7.8; pepsin (Merck Darmstad, Germany) in $0.002 \mathrm{~N} \mathrm{HCl}$; lipase (Merck) in $0.1 \mathrm{M}$ potassium phosphate, $\mathrm{pH}$ 6.0; papain (Sigma) in $0.05 \mathrm{M}$ sodium phosphate acetate, $\mathrm{pH}$ 7.0. All these solutions were filter-sterilised through Millex GV $0.22 \mathrm{~m}$ filters (Millipore S.A., St. Quentin-en-Yvelines, France) and then added to sterile cell-free supernatants (v/v, 1/ 1). Controls consisted of enzyme solutions without bacteriocin and only cell-free supernatant in $0.1 \mathrm{M}$ sodium phosphate buffer. The samples and controls were incubated at $37^{\circ} \mathrm{C}$ for $2 \mathrm{~h}$ and heated in boiling water for $5 \mathrm{~min}$ to inactivate the enzymes. The remaining bacteriocin activity was determined by the critical dilution assay of Mayr-Harting et al. (19) as described before, using B. cereus CTC 1 as indicator strain.

\section{RESULTS AND DISCUSSION}

\section{Bacterial isolation and screening}

Since bacteriocin-producing bacteria isolated from meat and products are well adapted to these conditions, they could ensure the safety and extend the shelf life of these foods. Therefore a search was made for antagonistic activities against food spoilage and pathogenic bacteria, in isolates from a range of meat and meat products.

According to the results, of a total of 285 different fresh meat and meat products samples analysed, 174 presented strains of lactic acid bacteria that were found to produce bacteriocinlike substances by the "sandwich" test. From each of these samples, at least 4 colonies capable of inhibiting $S$. aureus CTC 33 and/or L. innocua Lin 11 were isolated, representing a total of 813 colonies. De Martinis et al. (7) screened twenty samples of Brazilian meat and meat products and isolated four bacteriocinproducing lactic acid bacteria that presented antilisterial activity.

After purification, the cultures were then checked for bacteriocin production using the well-diffusion assay. Using this method, by inoculating the wells with broth cultures from various indicator microorganisms, comparisons may be made between the bacteriocin production of different strains growing under identical conditions. Of the 813 isolates, only $128(15.7 \%)$ produced inhibition zones on MRS agar. These bacteriocinproducing strains were all Gram-positive and catalase negative, $75.8 \%$ being cocci and $24.2 \%$ rods. Schillinger and Lücke (28) obtained similar results on checking Lactobacillus sake strains that were positive in the agar spot test and negative in the welldiffusion assay: of a total of 19 strains, only six produced inhibition zones on agar in the well-diffusion assay. Lewus et al. (16) found that only a few of the strains that tested positive using the spot-on-the-lawn method gave positive results in the well-diffusion assay. They considered that allowing some time for the bacteriocins to diffuse into the agar prior to incubation, or increasing the well size so that more sample could be applied, might increase the sensitivity of the assay. According to these authors, aggregation, non-diffusable bacteriocins, protease inactivation and concentration effects, can all lead to false negative results in the well-diffusion assay.

The results of the well-diffusion assay showed that $64.1 \%$ of the isolated strains only inhibited S. aureus, and $11.7 \%$ only showed inhibitory activity against $L$. innocua, whereas $24.2 \%$ of the meat isolates which inhibited $S$. aureus also inhibited $L$. innocua. According to Lewus et al. (16) the indicator microorganism used in the initial screening needs to reflect the final or proposed application of the bacteriocin-producing strain. S. aureus and Listeria sp. are often present in fresh tissues, because the slaughtering process does not include a bactericidal step. The growth of $S$. aureus in foods presents a potential public health hazard, since many strains of $S$. aureus produce enterotoxins that cause food poisoning if ingested. Meat and meat products are commonly associated with staphylococcal food poisoning $(25,36)$. Listeria species have been found in meat and meat products (13). Foodborne transmission of $L$. monocytogenes has been implicated in human outbreaks of listeriosis involving the consumption of various foods $(9,17,29)$. L. innocua is frequently isolated from meat, and often the incidence of this organism is higher than that of $L$. 
monocytogenes (2). The use of Listeria species other than $L$. monocytogenes as indicators of the presence of this organism has been proposed (39).

Fig. 1 shows the groups of meat and meat product samples that presented bacteriocin-like producing lactic acid bacteria, according to the "sandwich" test and well-diffusion assay. However, not all the bacteria isolated by the "sandwich" test were confirmed in the well-diffusion assay. The "sandwich" test presented $174(61.0 \%)$ positive samples for bacteriocintype producing organisms, of which only $55(31.1 \%)$ tested positive in the well-diffusion assay. According to the "sandwich" test, the majority of the bacteriocin-producing bacteria were isolated from matured, dried or fermented meat products (78.4\%). The same was not observed in the well-diffusion assay: fresh meat had the higher numbers of bacteriocin-producing bacteria (27.5\%). On the other hand, both methods showed that cooked meat products contained less samples with lactic acid bacteria positive for bacteriocin-like substances.

These negative results could show that bacteriocin production is not highly conserved in these strains. Some of the bacteriocins are plasmid-mediated proteins (34), so one should consider the possibility that some cultures could have lost their plasmids after consecutive transfers during the purification.

\section{Spectra of inhibitory activity}

The activity against 18 indicator strains, of the antibacterial compounds produced by the bacterial isolates, is shown in Table 2. These strains presented a broad inhibitory spectrum since they were able to inhibit many of the indicator strains tested. These data suggest that several different indicator microorganisms should be used in bacteriocin-screening tests, to avoid missing a producer. Of all the indicator strains tested, $S$. aureus CTC 33, Cl. sporogenes CTC 6, and B. cereus CTC 1 were the most sensitive, being inhibited by the greatest number

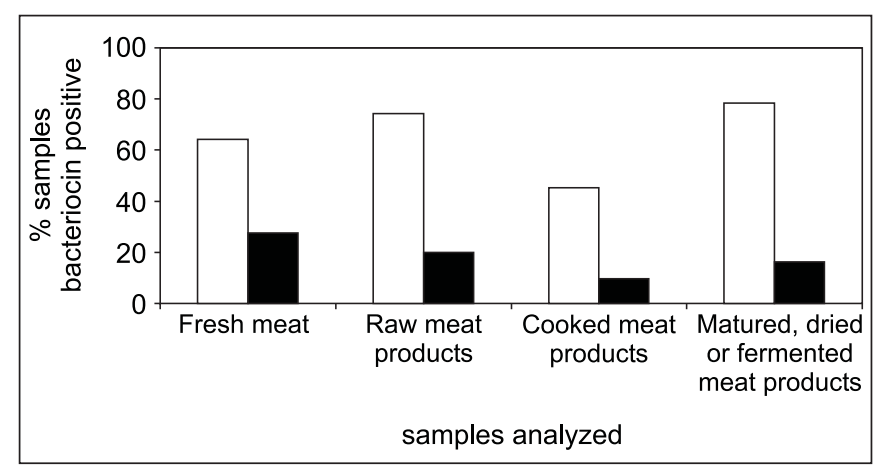

Figure 1. Meat and meat product samples positive for bacteriocin-like producing lactic acid bacteria in the $(\square)$ "sandwich" test and (ם) well-diffusion assay. of cultures, whereas Ent. faecalis ATCC 19433, Lb. plantarum TECNOLAT 434, sulphite-reducing clostridia CTC 5, Leuc. mesenteroides ATCC 10830, and W. viridescens CCT 849 were inhibited by a minor number of strains. Of the strains tested for bacteriocin production, none showed inhibitory activity against all the indicators. Only 4 strains (CTC 165, CTC 376, CTC 469, and CTC 484), inhibited the majority of the indicator strains tested (data not showed).

The majority of the inhibition caused by lactic acid strains produced "low" inhibition zones (radius of the clearance zone was lower than $3 \mathrm{~mm}$ ). Lb. helveticus (Wiesby) was a very sensitive indicator, since $90.2 \%$ of the inhibition caused by the bacteriocins tested over this bacterium produced "high" inhibition zones (radius of the clearance zone was higher than 5 $\mathrm{mm}$ ). The cultures that produced "high" inhibition zones against indicator strains were: CTC 3, CTC 12, CTC 35, CTC 36, CTC 38, CTC 40, CTC 49, CTC 51, CTC 78, CTC 141, CTC 142, CTC 144, CTC 172, CTC 176, CTC 185, CTC 204, CTC 205, CTC 206, CTC 210, СTC 211, CTC 212, CTC 231, CTC 253, СTC 330, СTC 346, CTC 352, CTC 359, CTC 375, CTC 376, CTC 377, CTC 378, CTC 396, CTC 404, CTC 469, CTC 483, CTC 484, and CTC 485 against Lb. helveticus; strains CTC 78 and CTC 172 against B. cereus CTC 001; strain CTC 172 against $C l$. sporogenes CTC 006; and strain CTC 332 against $C l$. perfringens CTC 42.

Some strains produced bacteriocin-type substances which inhibited the Gram-negative bacteria tested: Pseudomonas sp. CTC 32 was inhibited by 61 (47.6\%) strains, E. coli ATCC 25422 by $49(38.3 \%)$ strains, and Salm. typhimurium ATCC 14028 by $48(37.5 \%)$ strains. The target of bacteriocins is the cytoplasmic membrane, so due to the protective barrier provided by the LPS of the outer membrane of Gram-negative bacteria, bacteriocins are generally only active against Gram-positive cells (32). However, mutant strains or protoplasts of Gram-negative bacteria became sensitive to bacteriocin action after exposure to sub-lethal stress such as heating, freezing, or thawing, which disrupt the outer membrane and allow the access of bacteriocins to the cytoplasmic membrane, leading to an increased sensitivity $(11,30,32)$.

Of the 128 cultures tested for antimicrobial activity, the 12 that inhibited the greatest number of indicators were tested using the Mayr-Harting et al. (19) assay (Table 3). According to the results, B. cereus CTC 1 and L. monocytogenes CTC 21 were the most sensitive microorganisms tested since the lactic acid strains analysed inhibited $100 \%$ and $91.7 \%$ of them, respectively. A variation was noted with respect to the level of inhibition amongst the indicator strains tested. W. viridescens CCT 849 was the most resistant one, since it presented the lowest activity value. B. cereus ATCC 14579, Leuc. mesenteroides ATCC 10830, and the sulphite-reducing clostridia CCT 5, exhibited an intermediate sensitivity pattern, whilst $S$. aureus CTC 33, L. innocua Lin 11, L. monocytogenes CTC 21, and $\mathrm{Cl}$. perfringens CTC 42 were less resistant bacteria. The 
Table 2. Sensitivity of pathogenic and spoilage bacteria to bacteriocin-producing strains isolated from meat and meat products by the agar well-diffusion method.

\begin{tabular}{|c|c|c|c|c|c|}
\hline \multirow[t]{3}{*}{ Indicator strains } & \multicolumn{5}{|c|}{ Inhibitor producers } \\
\hline & \multirow[t]{2}{*}{ negative } & \multicolumn{4}{|c|}{ positive* } \\
\hline & & "low" & "average" & "high" & total \\
\hline B. cereus CTC 1 & $29(22.6 \%)$ & $85(66.4 \%)$ & $12(9.4 \%)$ & $2(1.6 \%)$ & $99(77.3 \%)$ \\
\hline B. cereus ATCC 14579 & $45(35.2 \%)$ & $57(44.5 \%)$ & - & - & $57(44.5 \%)$ \\
\hline Cl. perfringens CTC 42 & $34(26.6 \%)$ & $93(72.6 \%)$ & - & $1(0.8 \%)$ & $94(73.4 \%)$ \\
\hline Cl. sporogenes CTC 6 & $24(18.6 \%)$ & $94(73.4 \%)$ & $9(7.0 \%)$ & $1(0.8 \%)$ & $104(81.1 \%)$ \\
\hline Ent. faecalis ATCC 19433 & $121(94.5 \%)$ & $6(46.9 \%)$ & $1(0.8 \%)$ & - & $7(5.5 \%)$ \\
\hline E. coli ATCC 25422 & $79(61.7 \%)$ & $49(38.3 \%)$ & - & - & $49(38.3 \%)$ \\
\hline Lb. helveticus (Wiesby) & $87(68.0 \%)$ & $4(3.1 \%)$ & - & $37(28.9 \%)$ & $41(32.0 \%)$ \\
\hline Lb. plantarum TECNOLAT 434 & $121(94.5 \%)$ & $7(5.5 \%)$ & - & - & $7(5.5 \%)$ \\
\hline Leuc. mesenteroides ATCC 10830 & $104(81.2 \%)$ & $23(18.0 \%)$ & $1(0.8 \%)$ & - & $24(18.8 \%)$ \\
\hline L. iпnосиа $\operatorname{Lin} 11$ & $77(60.2 \%)$ & $49(38.3 \%)$ & $2(1.6 \%)$ & - & $51(39.8 \%)$ \\
\hline L. monocytogenes CTC 21 & $79(61.7 \%)$ & $48(37.5 \%)$ & $1(0.8 \%)$ & - & $49(38.3 \%)$ \\
\hline Micrococcus sp. ATCC 4698 & $63(49.2 \%)$ & $57(44.5 \%)$ & $6(4.7 \%)$ & - & $63(49.2 \%)$ \\
\hline Pseudomonas sp. CTC 32 & $67(52.3 \%)$ & $60(46.9 \%)$ & $1(0.8 \%)$ & - & $61(47.6 \%)$ \\
\hline Salm. typhimurium ATCC 14028 & $80(62.5 \%)$ & $48(37.5 \%)$ & - & - & $48(37.5 \%)$ \\
\hline S. aureus CTC 33 & $8(6.2 \%)$ & $119(93.0 \%)$ & $1(0.8 \%)$ & - & $120(93.8 \%)$ \\
\hline Streptococcus sp. ATCC 25175 & $99(77.3 \%)$ & $29(22.6 \%)$ & - & - & $29(22.6 \%)$ \\
\hline Sulphite-reducing clostridia CTC 5 & $108(84.4 \%)$ & $20(15.6 \%)$ & - & - & $20(15.6 \%)$ \\
\hline W. viridescens CCТ 849 & $104(81.2 \%)$ & $24(18.8 \%)$ & - & - & $24(18.8 \%)$ \\
\hline
\end{tabular}

*The inhibitory activity is expressed as the radius " $\mathrm{r}$ " of the clearance zone. Based on these results a division into 3 groups with increasing inhibitory activity was made ("low": $\mathrm{r}<3 \mathrm{~mm}$; "average": $3 \mathrm{~mm}<\mathrm{r}<5 \mathrm{~mm}$; "high": $\mathrm{r}>5 \mathrm{~mm}$ ).

Table 3. Activity spectra of bacteriocin produced by lactic acid cultures according to Mayr-Harting et al. (19).

\begin{tabular}{|c|c|c|c|c|c|c|c|c|c|c|c|c|}
\hline \multirow{2}{*}{ Indicators } & \multicolumn{12}{|c|}{ Activity of bacteriocin-producing bacteria $\left(A U / m L^{*}\right)$} \\
\hline & 141 & 164 & 204 & 210 & 352 & 368 & 396 & 404 & 469 & 483 & 484 & 485 \\
\hline B. cereus $\mathrm{CTC} 1$ & 800 & 800 & 200 & 200 & 200 & 400 & 800 & 400 & 1600 & 1600 & 200 & 1600 \\
\hline B. cereus ATCC 14578 & 0 & 0 & 0 & 0 & 0 & 0 & 0 & 0 & 0 & 0 & 400 & 400 \\
\hline Cl. perfringens $\mathrm{CTC} 42$ & 800 & 0 & 200 & 0 & 0 & 0 & 0 & 200 & 0 & 200 & 200 & 200 \\
\hline Cl. sporogenes $\mathrm{CTC} 6$ & 0 & 0 & 0 & 0 & 0 & 0 & 0 & 0 & 0 & 0 & 0 & 0 \\
\hline Ent. faecalis ATCC 19433 & 0 & 400 & 0 & 0 & 0 & 0 & 0 & 0 & 1600 & 0 & 200 & 0 \\
\hline E. coli ATCC 25422 & 0 & 0 & 0 & 0 & 0 & 0 & 0 & 0 & 0 & 0 & 0 & 0 \\
\hline Lb. helveticus (Wiesby) & 800 & 800 & 800 & 0 & 800 & 0 & 800 & 400 & 800 & 800 & 800 & 1600 \\
\hline Lb. plantarum TECNOLAT 434 & 0 & 0 & 0 & 0 & 0 & 0 & 0 & 0 & 0 & 0 & 0 & 0 \\
\hline Leuc. mesenteroides ATCC 10830 & 0 & 400 & 0 & 400 & 0 & 0 & 0 & 0 & 200 & 200 & 0 & 0 \\
\hline L. іппосиа $\operatorname{Lin} 11$ & 0 & 400 & 400 & 200 & 800 & 800 & 0 & 200 & 400 & 200 & 0 & 0 \\
\hline L. monocytogenes CTC 21 & 400 & 800 & 400 & 200 & 800 & 800 & 400 & 200 & 200 & 0 & 200 & 200 \\
\hline Micrococcus sp. ATCC 4698 & 0 & 0 & 0 & 0 & 0 & 0 & 0 & 0 & 0 & 0 & 0 & 0 \\
\hline Pseudomonas sp. СТC 32 & 0 & 0 & 0 & 0 & 0 & 0 & 0 & 0 & 0 & 0 & 0 & 0 \\
\hline Salm. typhimurium ATCC 14028 & 0 & 0 & 0 & 0 & 0 & 0 & 0 & 0 & 0 & 0 & 0 & 0 \\
\hline S. aureus CTC 33 & 200 & 200 & 400 & 0 & 800 & 800 & 0 & 0 & 200 & 200 & 200 & 0 \\
\hline Streptococcus sp. ATCC 25175 & 0 & 0 & 0 & 0 & 0 & 0 & 0 & 0 & 0 & 0 & 0 & 0 \\
\hline Sulphite-reducing clostridia CTC 5 & 0 & 0 & 0 & 0 & 0 & 0 & 0 & 0 & 400 & 0 & 0 & 0 \\
\hline W. viridescens CCT 0849 & 0 & 200 & 0 & 0 & 0 & 200 & 0 & 0 & 0 & 0 & 0 & 0 \\
\hline
\end{tabular}

* AU/mL: results expressed as activity units per millilitre. 
most sensitive microorganisms, B. cereus CTC 1, Ent. faecalis ATCC 19433, and Lb. helveticus (Wiesby) showed the highest sensitivities against some of the producers. Among the producers, strains CTC 210 and CTC 404 exhibited lower inhibition activity values, whilst strains CTC 469, CTC 483, and CTC 485 showed the highest activity. Of the strains tested, CTC 164 and CTC 469 showed the widest activity spectra, since they were able to inhibit $44.4 \%$ of the indicator cultures.

Some of the microorganisms that exhibited sensitivity towards the strains tested using the well-diffusion assay, such as the Gram-negative species (E. coli ATCC 25422, Pseudomonas sp. CTC 32, and Salm. typhimurium ATCC 14028), Cl. sporogenes CTC 6, Micrococcus $\mathrm{sp}$. ATCC 4698, Lb. plantarum TECNOLAT 434, and Streptococcus sp. ATCC 25175, were not inhibited in the Mayr-Harting et al. (19) assay. Only B. cereus CTC 1 exhibited the same pattern of sensitivity when analysed by both methods.

Indicator culture inhibition was greater using the welldiffusion assay. Since both the producer cultures and the indicators grew at the same time, the inhibition could be caused by a competition for nutrients from the culture media. The use of cell-free supernatants in the Mayr-Harting et al. (19) assay could avoid this problem.

\section{Sensitivity to proteolytic and lipolytic enzymes}

The sensitivity of the antibacterial substances produced by lactic acid bacteria to $\alpha$-chymotrypsin, trypsin, pronase $\mathrm{E}$, ficin, pepsin, papain, and lipase was determined in controlled and reproducible conditions shown in Table 4. All the compounds were fully or partially inactivated by some of the proteolytic enzymes, which indicates their proteinaceous nature.

In general, the inhibitory compounds produced by these strains presented different patterns of sensitivity. All of them were completely inactivated by $\alpha$-chymotrypsin, pronase $\mathrm{E}$, and ficin. Only one was resistant to trypsin (strain CTC 141), while the substance produced by strain CTC 204 lost $75 \%$ of its activity after treatment with this enzyme. Some authors differentiate nisin from other lactococcal bacteriocin by the fact that $\alpha$-chymotrypsin is the only proteolytic enzyme to which nisin is sensitive $(14,22)$. Nevertheless, this property is to be regarded with caution, since other authors have reported that nisin can also be inactivated by other enzymes such as pronase $\mathrm{E}(15,23)$, and ficin $(5,21)$.

Pepsin inhibited the antagonistic activity of $75 \%$ of the strains (CTC 141, CTC 164, CTC 210, CTC 368, CTC 396, CTC 404, CTC 483, CTC 484, and CTC 485). Sensitivity to pepsin was shown in other bacteriocins: plantaricin $35 \mathrm{~d}$ (20), sakacin A (28), and enterocin 416KI (27). Papain did not affect the activity of the antibacterial substances produced by strains CTC 141 and CTC 404, while this enzyme inactivated the other ones.

The compounds produced by strains CTC 164, CTC 210, CTC 368, CTC 483, CTC 484, and CTC 485, were fully or partially inactivated after treatment with lipase, indicating that these inhibitory substances may have a lipid moiety in their chemical composition.

It is interesting to note that the compounds produced by these strains were inactivated by an array of proteolytic enzymes, including those of pancreatic origin (trypsin and $\alpha$ chymotrypsin) and many times of gastric origin (pepsin). On the basis of the definition of bacteriocins of Gram-positive bacteria given by Tagg et al. (34) and Klaenhammer (14) and by using the properties observed in bacteriocins from lactic acid bacteria (22), the antibacterial compounds produced by the present strains can be classified as bacteriocins. The pattern of protease sensitivity indicates the singularity of the bacteriocins produced by the isolates and that the strains are different. Although some of the bacteriocins presented similar pattern of protease sensitivity, as between CTC 210 and CTC 484 or CTC 352 and CTC 469, they did not share an identical spectrum of activity.

Table 4. Sensitivity of bacteriocins produced by lactic acid strains to treatment with proteolytic and lipolytic enzymes.

\begin{tabular}{|c|c|c|c|c|c|c|c|c|c|c|c|c|}
\hline \multirow{2}{*}{ Enzymes } & \multicolumn{12}{|c|}{ Strains } \\
\hline & 141 & 164 & 204 & 210 & 352 & 368 & 396 & 404 & 469 & 483 & 484 & 485 \\
\hline Control* & 800 & 800 & 800 & 200 & 200 & 400 & 800 & 400 & 1600 & 1600 & 200 & 1600 \\
\hline$\alpha$-Chymotrypsin & 0 & 0 & 0 & 0 & 0 & 0 & 0 & 0 & 0 & 0 & 0 & 0 \\
\hline Trypsin & 800 & 0 & 200 & 0 & 0 & 0 & 0 & 0 & 0 & 0 & 0 & 0 \\
\hline Pronase $\mathrm{E}$ & 0 & 0 & 0 & 0 & 0 & 0 & 0 & 0 & 0 & 0 & 0 & 0 \\
\hline Ficin & 0 & 0 & 0 & 0 & 0 & 0 & 0 & 0 & 0 & 0 & 0 & 0 \\
\hline Pepsin & 0 & 400 & 800 & 0 & 200 & 0 & 0 & 200 & 1600 & 400 & 0 & 400 \\
\hline Papain & 800 & 0 & 0 & 0 & 0 & 0 & 200 & 400 & 0 & 200 & 0 & 0 \\
\hline Lipase & 800 & 400 & 800 & 0 & 200 & 200 & 800 & 400 & 1600 & 400 & 0 & 400 \\
\hline
\end{tabular}

* Phosphate buffer + cell-free supernatants. 
The results showed that $61 \%$ of the meat samples analysed presented bacteriocin-producing lactic acid bacteria with potential to inhibit harmful microorganisms, such as $L$. monocytogenes, $S$. aureus, and sporulated bacteria. The antimicrobial activity of the bacteriocins produced by the lactic acid bacteria isolated in this research could act as a barrier to inhibit food spoilage and/or growth of pathogenic microorganisms in foods. Further work to evaluate the nature of these substances and their applicability in biopreservation techniques for meats is in progress.

\section{ACKNOWLEDGEMENTS}

The authors thank FAPESP (Fundação de Amparo a Pesquisa do Estado de São Paulo) for financial support (Process 99/12314-0).

\section{RESUMO}

\section{Isolamento de bactérias lácticas produtoras de bacteriocinas a partir de carnes e produtos cárneos e seu espectro de atividade inibitória}

Um total de 285 amostras de carnes e produtos cárneos foi avaliado para detecção de culturas produtoras de bacteriocinas pelo método do "sanduíche". A partir de 174 destas amostras, 813 linhagens de bactérias lácticas com atividade inibitória sobre Staphylococcus aureus CTC 033 e/ou Listeria innocua Lin 11 foram isoladas. Quando examinadas pelo método de antagonismo simultâneo em poços, 128 destas linhagens inibiram o crescimento dos microrganismos indicadores. $\mathrm{O}$ espectro de atividade das linhagens isoladas foi avaliado com diversos microrganismos Gram-positivos e Gram-negativos. De um modo geral, S. aureus foi o microrganismo indicador mais sensível, enquanto Enterococcus faecalis e Lactobacillus plantarum foram os mais resistentes. Todos os compostos antimicrobianos produzidos pelas bactérias lácticas testadas foram completa ou parcialmente inativados por enzimas proteolíticas, o que indica sua natureza protéica. A atividade antimicrobiana das bacteriocinas produzidas pelas linhagens de bactérias lácticas isoladas neste trabalho pode atuar como uma barreira potencial para inibir o crescimento de bactérias deterioradoras e patogênicas de origem alimentar.

Palavras-chave: bactérias lácticas, bacteriocinas, carne, atividade inibitória

\section{REFERENCES}

1. Benkerroum, N.; Ghouati, Y.; Sandine, W.E.; Tantaoui-Elaraki, A. Methods to demonstrate the bactericidal activity of bacteriocins. Letters Appl. Microbiol., 17: 80-81, 1993.

2. Breer, C.; Schopfer, K. Listeria and food. Lancet ii, 1022, 1988.
3. Campanini, M.; Pedrazzoni, I.; Barbuti, S.; Baldini, P. Behaviour of Listeria monocytogenes during the maturation of naturally and artificially contaminated salami: effect of lactic acid bacteria starter cultures. Int. J. Food Microbiol., 20: 169-175, 1993.

4. Caplice, E.; Fitzgerald, G.F. Food fermentations: role of microorganisms in food production and preservation. Int. J. Food Microbiol., 50(1-2): 131-149, 1999.

5. Carminati, D.; Giraffa, G.; Bossi, M. Bacteriocin-like inhibitors of Streptococcus lactis against Listeria monocytogenes. J. Food Prot., 52(9): 614-617, 1989.

6. Cleveland, J.; Montville, T.J.; Nes, I.F.; Chikindas, M.L. Bacteriocins: safe, natural, antimicrobials for food preservation. Int. J. Food Microbiol., 71: 1-20, 2001.

7. De Martinis, E.C.P.; Públio, M.R.P.; Santarosa, P.R.; Freitas, F.Z Antilisterial activity of lactic acid bacteria isolated from vacuumpacked Brazilian meat ant meat products. Braz. J. Microbiol., 32(1): 32-37, 2001.

8. De Vuyst, L.; Vandamme, E. Nisin, a lantibiotic produced by Lactococcus lactis subsp. lactis: properties, biosynthesis and applications. In: De Vuyst, L.; Vandamme, E. (eds.). Bacteriocins of lactic acid bacteria. Microbiology, genetics and applications. Blackie Academic and Professional, London, 1994, p.151-221.

9. Fleming, D.W.; Cochi, S.L.; MacDonald, K.L.; Brondum, J.; Hayes, P.S.; Plikaytis, B.D.; Holmes, M.B.; Audurier, A.; Broomer, C.V.; Reingold, A.L. Pasteurized milk as a vehicle of infection in an outbreak of listeriosis. N. Engl. J. Med., 312: 404-407, 1985.

10. Harrigan, W.F.; McCance, M.E. Basic methods. In: Harrigan, W.F.; McCance, M.E. (eds.). Laboratory methods in food and dairy microbiology. Academic Press, London, 1976, p.1-115.

11. Hauben, K.; Wuytack, E.; Soontjens, C.C.F.; Michiels, C.W. Highpressure transient sensitization of Escherichia coli to lysozyme and nisin by disruption of outer-membrane permeability. J. Food Prot., 59: 350-355, 1996.

12. Hugas, M.; Monfort, J.M. Bacterial starter cultures for meat fermentation. Food Chem., 59(4): 547-554, 1997.

13. Johnson, J.L.; Doyle, M.P.; Cassens, R.G. Listeria monocytogenes and other Listeria spp. in meat and meat products. A review. J. Food Prot., 53(1): 81-91, 1990.

14. Klaenhammer, T.R. Bacteriocins of lactic acid bacteria. Biochimie, 70: 337-349, 1988.

15. Kojic, M.; Svircevic, J.; Banina, A.; Topisirovic, L. Bacteriocinproducing strain of Lactococcus lactis subsp. diacitilactis S50. Appl. Environ. Microbiol., 57(6): 1835-1837, 1991.

16. Lewus, C.B.; Kaiser, A.; Montville, T.J. Inhibition of food-borne pathogens by bacteriocins from lactic acid bacteria isolated from meat. Appl. Environ. Microbiol., 57(6): 1683-1688, 1991.

17. Linnan, M.J.; Mascola, L.; Lou, X.D.; Goulet, V.; May, S.; Salminen, C.; Hird, D.W.; Yonekura, M.L.; Hayes, P.; Weaver, R.; Audurier, A.; Plikaytis, B.D.; Fannin, S.L.; Kleks, A.; Broome, C.V. Epidemic listeriosis associated with Mexican-style cheese. N. Engl. J. Med., 319: 823-828, 1988.

18. Lücke, F-K. Utilization of microbes to process and preserve meat. Meat Sci., 56: 105-115, 2000.

19. Mayr-Harting, A.; Hedges, A.J.; Berkeley, C.W. Methods for studying bacteriocins. In: Norris, J.R.; Ribbons, D.W. (eds.). Methods in Microbiology. Academic Press Inc., New York, 1972, p.316-422.

20. Messi, P.; Bondi, M.; Sabia, C.; Battini, R.; Manicardi, G. Detection and preliminary characterization of a bacteriocin (plantaricin 35d) produced by a Lactobacillus plantarum strain. Int. J. Food Microbiol. 64: 193-198, 2001.

21. Moreno, I.; Lerayer, A.L.S.; Baldini, V.L.S.; Leitão, M.F.F. Characterization of bacteriocins produced by Lactococcus lactis strains. Braz. J. Microbiol., 31(3): 184-192, 2000. 
22. Piard, J.C.; Desmazeaud, M. Inhibition factors produced by lactic acid bacteria. 2. Bacteriocins and other antibacterial substances. Lait, 72: 113-142, 1992.

23. Rammelsberg, M.; Radler, F. Antibacterial polypeptides of Lactobacillus species. J. Appl. Bacteriol., 69: 177-184, 1990.

24. Rayman, K.; Malik, N.; Hurst, A. Failure of nisin to inhibit outgrowth of Clostridium botulinum in a model cured meat system. Appl. Environ. Microbiol., 46: 1450-1452, 1983.

25. Roberts, D. Bacteria of public health significance. In: Brown, M.H. (ed.) Meat microbiology. Applied Science Publishers Ltd., London, 1982, p.319-386.

26. Rose, N.L.; Sporns, P.; Stiles, M.E.; McMullen, L.M. Inactivation of nisin by glutathione in fresh meat. J. Food Sci., 64(5): 759-762, 1999.

27. Sabia, C.; Manicardi, G.; Messi, P.; Niederhäusern, S.; Bondi, M. Enterocin 416K1, an antilisterial bacteriocin produced by Enterococcus casseliflavus IM 416K1 isolated from Italian sausages. Int. J. Food Microbiol., 75: 163-170, 2002.

28. Schillinger, U.; Lücke, F-K. Antibacterial activity of Lactobacillus sake isolated from meat. Appl. Environ. Microbiol., 55(8): 19011906, 1989.

29. Schlech, W.F.; Lavigne, P.M.; Bortolussi, R.A.; Allen, A.C.; Haldane, E.V.; Wort, A.J.; Hightower, A.W.; Johnson, S.E.; King, S.H.; Nicholls, E.S.; Broome, C.V. Epidemic listeriosis-evidence for transmission by food. N. Eng. J. Med., 308: 203-204, 1983.

30. Schved, F.; Henis, Y.; Juven, B.J. Response of spheroplasts and chelator-permeabilized cells of Gram-negative bacteria to the action of the bacteriocin pediocin SJ-1 and nisin. Int. J. Food Microbiol., 21: 305-314, 1994.

31. Shahidi, F. Developing alternative meat-curing systems. Trends Food Sci. Technol., 2: 219-222, 1991.

32. Stevens, K.A.; Sheldon, B.W.; Klapes, N.A.; Klaenhammer, T.R. Nisin treatment for inactivation of Salmonella species and other Gramnegative bacteria. Appl. Environ. Microbiol., 57: 3613-3615, 1991.

33. Stiles, M.E.; Hastings, J.W. Bacteriocin production by lactic acid bacteria: Potential for use in meat preservation. Trends Food Sci. Technol., 2: 247-251, 1991.

34. Tagg, J.R.; Dajani, A.S.; Wannamaker, L.W. Bacteriocins of grampositive bacteria. Bacteriol. Rev., 40: 722-756, 1976.

35. Tagg, J.R.; McGiven, A.R. Assay system for bacteriocins. Appl. Microbiol., 21(5): 943, 1971.

36. Varnam, A.H.; Sutherland, J. Cooked cured meats. In: Varnam, A.H.; Sutherland, J.P. (eds.). Meat and meat products. Technology, chemistry and microbiology. Chapman \& Hall, London, 1995, p.298-313.

37. Yang, R.; Ray, B. Prevalence and biological control of bacteriocinproducing psychrotrophic leuconostocs associated with spoilage of vacuum-packaged processed meats. J. Food Prot., 57(3): 209-217, 1994.

38. Yousef, A.E.; Luchansky, J.B.; Degnan, A.K.; Doyle, M.P. Behaviour of Listeria monocytogenes in Wiener exsudates in the presence of Pediococcus acidilactici $\mathrm{H}$ or pediocin $\mathrm{AcH}$ during storage at 4 or 25ㄷ. Appl. Environ. Microbiol., 57: 1461-1467, 1991.

39. World Health Organization Informal Working Group on Foodborne Listeriosis. Foodborne listeriosis. Document ${ }^{\circ}$ WHO/WHE/FOS/ 88.5. World Health Organization: Geneva, Switzerland, 1988. 